\title{
Evaluation of the Acute Oral Toxicity Class of Trinuclear Chromium(III) Glycinate Complex in Rat
}

\author{
Halina Staniek • Zbigniew Krejpcio • \\ Katarzyna Iwanik • Henryk Szymusiak • \\ Daria Wieczorek
}

Received: 13 December 2010 / Accepted: 5 January 2011 /

Published online: 18 January 2011

(C) The Author(s) 2011. This article is published with open access at Springerlink.com

\begin{abstract}
Chromium(III) is considered as an essential element playing a role in carbohydrate and lipid metabolism, and various chemical forms of this element are widely used in dietary supplements. A new trinuclear chromium(III) glycinate complex $\left[\mathrm{Cr}_{3} \mathrm{O}\left(\mathrm{NH}_{2} \mathrm{CH}_{2} \mathrm{CO}_{2}\right)_{6}\right.$ $\left.\left(\mathrm{H}_{2} \mathrm{O}\right)_{3}\right]^{+} \mathrm{NO}_{3}{ }^{-}$(CrGly), an analogue of $\mathrm{Cr} 3$ (trinuclear $\mathrm{Cr}(\mathrm{III})$ propionate complex) has been synthesized as a potential source of supplementary $\mathrm{Cr}$. In this study, we evaluated the acute toxicity class of CrGly in Wistar rats applying the OECD 423 procedure. Male and female Wistar rats $(n=12,6+9$ and 6 त) were given by gavage either a single dose of CrGly $2,000 \mathrm{mg} / \mathrm{kg}$ body mass (equals to $300 \mathrm{mg} \mathrm{Cr}(\mathrm{III}) / \mathrm{kg}$ body mass; in aqueous solution) or equivalent volumes of distilled water and fed ad libitum commercial Labofeed B diet, and observed carefully for 14 days, then sacrificed to collect blood and internal organs for biochemical and histologic examination. No death cases were detected. No abnormalities in animal behavior, body mass gains, gross organ histology, or blood morphology and biochemistry were observed. The results demonstrate that $\mathrm{LD}_{50}$ of CrGly is greater than $2,000 \mathrm{mg} / \mathrm{kg}$ when administrated orally to rat; thus, this compound appears to belong to the fifth category in the GHS system or the fourth class ("unclassified") in the EU classification system.
\end{abstract}

H. Staniek $\cdot$ Z. Krejpcio $(\bowtie)$

Department of Human Nutrition and Hygiene, Poznan University of Life Sciences,

31 Wojska Polskiego, 60-624 Poznan, Poland

e-mail: zkre@up.poznan.pl

Z. Krejpcio

College of Health, Beauty and Education, 3 Brzeznicka, 60-133 Poznan, Poland

K. Iwanik

Department of Clinical Pathology, Poznan University of Medical Sciences,

49 Przybyszewskiego, 60-355 Poznan, Poland

H. Szymusiak

Department of Product Ecology, Poznan University of Economics, 10 al. Niepodległosci, 61-875

Poznan, Poland

D. Wieczorek

Department of Technology and Environmental Protection, Poznan University of Economics, $10 \mathrm{al}$.

Niepodległosci, 61-875 Poznan, Poland 
Keywords Chromium(III) glycinate complex $\cdot$ Acute oral toxicity $\cdot$ Rat

\section{Introduction}

For 50 years, trivalent chromium $(\mathrm{Cr})$ has been considered as an essential element playing an important role in carbohydrate and lipid metabolism and providing significant beneficial effects in the insulin system [1-4]. These effects appear to be related to an increase in insulin sensitivity, with the proposed mechanisms reviewed in detail by Vincent and Bennett [5]. However, the failure to identify the responsible biomolecules that bind $\mathrm{Cr}$ and their mode of action made researchers to readdress the essentiality of this element [6]. In short, the main controversy exists as to whether dietary supplementation with $\mathrm{Cr}$ should be routinely recommended in subjects without documented deficiencies. The majority of studies showed that supplementing the diet with nutritionally relevant quantities of $\mathrm{Cr}$ does not give any beneficial effects, while effects from Cr may arise at pharmacological doses [6, 7]. Recent data fail to demonstrate a significant improvement in carbohydrate metabolism in individuals with metabolic syndrome, impaired glucose tolerance, or consistently in individuals with type 2 diabetes after $\mathrm{Cr}$ supplementation. Wang et al. [8] suggested that only a subgroup of type 2 diabetic subjects respond positively to $\mathrm{Cr}$ supplementation and subject's phenotype appears to be very important when assessing the clinical response to Cr. Wang and Celafu [9] recently postulated that patient selection may be an important factor in determining clinical response to $\mathrm{Cr}$ (decreased glucose and improved insulin sensitivity), as it may be more likely in insulin-resistant individuals with type 2 diabetes who have more elevated fasting glucose and hemoglobin $\mathrm{A}(1 \mathrm{c})$ levels.

Despite these controversies, over last decades $\mathrm{Cr}$ nutritional supplements become very popular for weight loss, muscle development, and diabetes. As $\mathrm{Cr}$ supplements various chemical forms of $\mathrm{Cr}(\mathrm{III})$, including $\mathrm{Cr}$ picolinate (CrPic), $\mathrm{Cr}$ histidinate (CrHis), $\mathrm{Cr}$ nicotinate (CrNic; also known as $\mathrm{Cr}$ niacinate $(\mathrm{CrN})$ ), and a $\mathrm{Cr}$ complex of D-phenylalanine $\left(\mathrm{Cr}(\mathrm{D}-\mathrm{phe})_{3}\right)$ have been used, patented, manufactured, and/or marketed worldwide.

The most popular chemical forms of $\mathrm{Cr}$ (III) used in dietary supplements are $\mathrm{Cr}(\mathrm{III})$ trispicolinate ( $\mathrm{CrPic}$ ) and $\mathrm{Cr}$ (III) nicotinate (CrNic). Over the last decades, sales of $\mathrm{CrPic}$, as a nutritional supplement for weight loss and increasing muscle mass, were increasing, and the supplement was drawing interest for its potential use in alleviating symptoms of type 2 diabetes. The beneficial action of CrPic on glucose and lipid metabolism and its helpful role in the treatment of diabetes has been documented, but the mechanisms of action are not well understood. On the other hand, CrPic has some drawbacks as a nutritional supplement. It has very limited solubility in water $(0.6 \mathrm{mM}$, at near neutral $\mathrm{pH})$ and stability (decreases in lower $\mathrm{pH}$ until the complex hydrolyzes to release picolinic acid) [7, 10], which is responsible for its low gastrointestinal absorption rate as $1 \%$ [6]. The safety of $\mathrm{Cr}$ (III) compounds used for dietary supplements has been a matter of considerable debate over last decades. The discussion about the toxic effects produced by CrPic have been reviewed recently [11] and will not be repeated in this article. Because there is widespread human exposure to CrPic in dietary supplements, recently Stout et al. [12] conducted toxicity and carcinogenicity studies of this compound (in the monohydrate form) in male and female $\mathrm{F} 344 / \mathrm{N}$ rats and $\mathrm{B} 6 \mathrm{C} 3 \mathrm{~F} 1$ mice exposed in feed to concentrations of $0,2,000,10,000$, or 50,000 ppm for 2 years. Exposure to $\mathrm{CrPic}$ did not induce biologically significant changes in survival, body mass, feed consumption, or nonneoplastic lesions in rats or mice. In male rats, however, a statistically significant increase in the incidence of preputial gland adenoma at 10,000 ppm was considered an equivocal finding. $\mathrm{CrPic}$ was not carcinogenic to female rats or to male or female mice. 
Among the $\mathrm{Cr}$ compounds (other than $\mathrm{CrPic}$ and $\mathrm{CrNic}$ ) proposed for dietary supplements and therapeutics, of particular interest is the $\mathrm{Cr}$ (III) propionate cation (CrProp), $\left[\mathrm{Cr}_{3} \mathrm{O}\left(\mathrm{O}_{2} \mathrm{CCH}_{2} \mathrm{CH}_{3}\right)_{6}\left(\mathrm{H}_{2} \mathrm{O}\right)_{3}\right]^{+}$, known as $\mathrm{Cr}_{3}$ [2, 13-18]. This compound belongs to the trinuclear oxo-centered metal carboxylate assemblies of the general formula $\left[\mathrm{Me}_{3} \mathrm{O}\left(\mathrm{O}_{2} \mathrm{CR}\right)_{6} \mathrm{~L}_{3}\right]^{+}(\mathrm{Me}=$ trivalent $3 \mathrm{~d}$ metal, $\mathrm{R}=$ aliphatic or aromatic group, $\mathrm{L}=$ monodentate ligand). CrProp was found to mimic the ability of low-molecular-weight chromium-binding substance or chromodulin to stimulate tyrosine kinase activity of the insulin receptor. Clodfelder et al. [18] reported that $\left[\mathrm{Cr}_{3} \mathrm{O}\left(\mathrm{O}_{2} \mathrm{CCH}_{2} \mathrm{CH}_{3}\right)_{6}\left(\mathrm{H}_{2} \mathrm{O}\right)_{3}\right]^{+}$is absorbed with very high efficiency of $40-60 \%$, while popular $\mathrm{Cr}$ supplements such as: $\mathrm{CrCl}_{3}, \mathrm{Cr}(\mathrm{III})$ nicotinate, or $\mathrm{CrPic}$ are absorbed at only $0.5-1.3 \%$ of the gavaged dose. The difference in the degree of absorption is readily explained by the stability and solubility of the cation in the physiological milieu. The biological activity and safety of CrProp has been studied on various experimental models. This compound given at a wide range of dosages (up to $2,000 \mathrm{mg} / \mathrm{kg}$ body mass) to experimental animals was confirmed to be safe [19-24] and does not exert genotoxic effects $[25,26]$.

Having assumed that the trinuclear oxo-centered $\mathrm{Cr}$ carboxylate structure is the key element that determines high bioavailability and biological activity of a $\mathrm{Cr}$ (III) compound, we synthesized a novel Cr(III) complex with glycine (CrGly), an analogue of CrProp. Its fundamental physicochemical properties were determined with the use of thermoanalytical and spectroscopic methods and compared to that of well-known trinuclear chromium(III) complex with propionic acid. The new complex, similarly as previously studied CrProp, in contrast to $\mathrm{CrPic}$ and $\mathrm{CrNic}$, is also well soluble in water and thermally stable until temperature of at least $220^{\circ} \mathrm{C}[27,28]$.

The CrGly biological activity (together with other Cr(III) compounds, like chromium chloride, histidinate, lactate, acetate, and propionate) was already tested in vitro, using three experimental models: isolated rat liver membranes, cultured mouse C2C12 myoblasts, and 3T3-L1 preadipocytes [29]. It was found that the examined $\mathrm{Cr}$ (III) compounds, in contrast to the results of other lab experiments in vitro (which may be related to the specific experimental conditions applied in this experiment), did not elevate the binding of insulin to the liver membranes. Moreover, chromium histidinate, lactate, acetate, and propionate complexes diminished the specific binding of insulin. Simultaneously, chromium chloride, which did not significantly elevate insulin binding, increased the number of membrane accessible particles of the insulin receptors. However, it was accompanied by slightly diminished affinity of the receptor to the hormone. Chromium acetate and propionate significantly diminished the binding capacity of the low-affinity insulin receptor class. Investigations with the myoblast cell line $\mathrm{C} 2 \mathrm{C} 12$ and preadipocyte cell line 3T3-L1 did not allow differentiation of the influence of the examined complexes on insulin binding. Immunodetection of phosphorylated forms of IRS-1 showed that the chromium compounds modulated the transduction of the insulin signal. Chromium glycinate, acetate, and propionate decreased the amount of IRS-1 phosphorylated at serine. Since it is generally thought that phosphorylation of serine in IRS-1 may moderate insulin action, the above-mentioned chromium complexes may, in this way, enhance insulin effects inside target cells. Phosphorylation of tyrosine in IRS-1, which acts as a stimulatory signal for further steps of insulin action, was elevated after the incubation of 3T3-L1 cells with insulin. Cr(III) did not additionally intensify this process. However, in the absence of insulin, chromium glycinate and acetate slightly elevated the level of IRS-1 phosphorylated at tyrosine. This fact may be important in vivo at low levels of insulin in blood. The results indicate that the action of chromium(III) complexes, including CrGly, involves a direct effect on the number of receptors accessible to insulin, 
their affinity to the hormone, and the modulation of the signal multiplying proteins by their phosphorylation.

In the present study, we focused on the determination of the acute toxicity class of CrGly (as an analogue of CrProp), when administered orally in a single dose to Wistar rats. The study was performed in compliance with the Organization for Economic Cooperation and Development (OECD) Guidelines for Testing Chemicals [30].

\section{Material and Methods}

\section{Test Chemicals}

Chromium(III) complex with glycine (CrGly) in the form of nitrate salt (chemical formula $\left[\mathrm{Cr}_{3} \mathrm{O}\left(\mathrm{NH}_{2} \mathrm{CH}_{2} \mathrm{CO}_{2}\right)_{6}\left(\mathrm{H}_{2} \mathrm{O}\right)_{3}\right]^{+} \mathrm{NO}_{3} \cdot \mathrm{H}_{2} \mathrm{O}$, the theoretical content of $\left.\mathrm{Cr} 25.7 \%\right)$, as an analogue of chromium(III) propionate (CrProp; chemical formula $\left[\mathrm{Cr}_{3} \mathrm{O}\right.$ $\left.\left.\left(\mathrm{O}_{2} \mathrm{CCH}_{2} \mathrm{CH}_{3}\right)_{6}\left(\mathrm{H}_{2} \mathrm{O}\right)_{3}\right]^{+} \mathrm{NO}_{3}\right)$ was synthesized in our laboratory according to the method described previously [28]. The product was recrystallized from water and then desiccated under vacuum in temperature of $100^{\circ} \mathrm{C}$. The product has a form of purple crystals, well soluble in water. To ensure that molecular structure of synthesized complex corresponds with the structure of the well-known chromium(III) propionate complex $(\mathrm{Cr} 3)$ propionic acid, some physicochemical properties of the new compounds were determined, including thermal stability was determined by using DTA and TGA methods (module DTA-50, Shimadzu). UV-VIS absorption spectra were obtained using Genesys 2 spectrophotometer. IR spectra were recorded in $\mathrm{KBr}$ using Specord M-80 spectrophotometer [27, 28]. The analytically determined content of elemental $\mathrm{Cr}$ in the compound (17.3\%) was determined by the AAS method (spectrometer AAS-3 with BC correction, Zeiss, Germany).

Acute Oral Toxicity Study in Male and Female Rats

For determination of the Acute Toxicity Class of CrGly, The OECD 423 Guideline For Testing of Chemicals Acute Oral Toxicity-Acute Toxic Class Method [30] procedures were applied as an alternative to the oral $\mathrm{LD}_{50}$ test [31]. Since the previous acute toxicity study demonstrated that $\mathrm{LD}_{50}$ of CrProp is greater than $2,000 \mathrm{mg} / \mathrm{kg}$ when administrated orally to rat, it was hypothesized that its analogue with glycine (CrGly) might also have a low toxicity potential and mortality is unlikely, thus the test procedure applied with a starting dose of $2,000 \mathrm{mg} / \mathrm{kg}$ body mass (per three animals of each sex). According to the 19th paragraph of the OECD-GL 423 procedure (OECD-GL 423, adopted in 17 December 2001) [30], when available information suggests that mortality is unlikely at the highest starting dose level $(2,000 \mathrm{mg} / \mathrm{kg}$ body weight), then a limit test should be conducted. The limit test is primarily used in situations where the experimenter has information indicating that the test material is likely to be non-toxic, i.e., having toxicity only above regulatory limit doses.

Male and female Wistar rats ( $n=12,6$ and 6 \% ; age 12-14 weeks old), obtained from Department of Toxicology Medical University of Poznan, Poland, were housed in the University-approved animal facility in rooms maintained at $22 \pm 2^{\circ} \mathrm{C}$, with $55-60 \%$ humidity and $12-\mathrm{h}$ photoperiod. After a 5-day adaptation to laboratory conditions, rats were divided

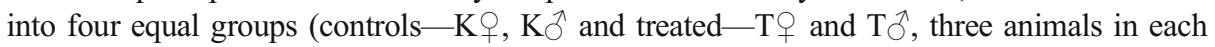


group, equal body mass) and given by gavage either a single dosage of 2,000 $\mathrm{mg}$ CrGly (in aqueous solution) $/ \mathrm{kg}$ body mass (treated groups, $\mathrm{T}+$ and $\mathrm{T}^{\hat{}}$ ), or equal volumes of distilled water (control groups, $\mathrm{K}+$ and $\mathrm{K} \precsim$ ), using a suitably graduated syringe and a stainless steel intubation cannula. The single dosage of CrGly equals approximately $420 \mathrm{mg} \mathrm{Cr} / \mathrm{kg}$ body mass/rat. Rats had free access to distilled water and commercial Labofeed B diet composed of cereal grains (wheat, rye, soybeans, flax seeds), brewery yeast, potato protein, milk and whey powder, mineral, and vitamin mix. The chemical composition of this diet (calculated per dry mass) was as follows: protein $(19.4 \%)$, fat $(3.3 \%)$, dietary fiber $(6.9 \%)$, crude ass $(6.5 \%)$, carbohydrates (63.9\%), and metabolic energy $(12.5 \mathrm{MJ} / \mathrm{kg})$. The dietary $\mathrm{Cr}$ content was determined by the AAS method $(1.5 \mathrm{mg} / \mathrm{kg}$ diet $)$

Animals were observed individually after dosing at least once during the first $30 \mathrm{~min}$, periodically during the first $24 \mathrm{~h}$, with special attention given during the first $4 \mathrm{~h}$, and daily thereafter, for a total of 14 days. All observations were systematically recorded with individual records being maintained for each animal. Individual body masses of animals were determined shortly before the test substance was administered and weekly thereafter. All the animals were sacrificed at the end of the observation period and subjected to a necropsy. All the procedures applied on animals were approved by the Local Bioethical Commission in Poznan (No. 48/2005).

Data Collection

At the end of the test (14-day of experiment), animals, after 16-h starvation, were weighed and euthanized by intraperitoneal injection of thiopental $(40 \mathrm{mg} / \mathrm{kg}$ body mass) and dissected to collect blood for morphological and biochemical studies and harvest internal organs (liver, kidney, spleen, heart) for microscopic examination.

\section{Laboratory Analyses}

Blood hemoglobin $(\mathrm{Hb})$ level was determined by the Drabkin's cyanohemoglobin method. Red blood count and related morphology indices were obtained by analytical hematology system CELLDYN-1700 [32].

Blood serum indices were determined by the following methods: glucose concentration by the UV photometric method [33] and total, LDL, HDL, and triacylglycerol concentrations by the colorimetric methods [34-36] using Olympus AU 560 equipment.

Activity of ALT, AST, and AP enzymes was measured by the kinetic methods [37], while urea concentration was measured by the kinetic method using urease and glutamine dehydrogenase [38]. Total protein concentration was measured by the colorimetric method using $\mathrm{Cu}^{2+}$ ions [39], and creatinine concentration was measured by the Jaffe's kinetic method with picric acid [38]. The serum Fe concentration was determined by the colorimetric method with 2,4,6-tri(2-pyridylo)-5-triazine [40]. The serum $\mathrm{Na}$ and $\mathrm{K}$ concentrations were measured by the photometric method using CORMING-614 analyzer [41].

\section{Histology}

A 3- to 5-mm section of the representative tissue (liver and kidney) was collected at the time of sacrifice and preserved in $10 \%$ buffered formalin. Sections were processed by standard histologic methods and embedded in paraffin. Slices were prepared and stained with hematoxylin and eosin [42]. 


\section{Data Analysis}

All the analytical data are presented as means $\pm \mathrm{SD}$, and observations for each rat were recorded and presented in tables, while histologic images of liver and kidney tissue were shown in figures.

\section{Results and Discussion}

As has been reported previously [11], the analysis of the toxicity is often a first step in the study of biological properties of the compounds. The oral acute toxic class method (ATC method) was developed as an alternative to replace the oral $\mathrm{LD}_{50}$ test. The ATC method is a sequential testing procedure using only three animals of one sex per step at any of the defined dose levels. Depending on the mortality rate of three, but never more than six, animals are used per dose level. This approach results in the reduction of numbers of animals used in comparison to the $\mathrm{LD}_{50}$ test by $40-70 \%$. For the above reasons described previously [11], this method was applied to test the acute toxicity class for CrGly.

Male and female Wistar rats, after administration of CrGly $(2,000 \mathrm{mg} / \mathrm{kg}$ body mass $)$ and neutral carrier (distilled water) by gavage, were observed carefully during the 14-day experimental period. None of the treated animals died during this period. Also no pathological changes were noticed in skin, fur, and eyes, as well as in their behavior in comparison with the control groups.

After 14 days of observations, all the rats were sacrificed and dissected to collect blood from heart and remove internal organs for gross and histopathologic observations. No pathological changes were observed in liver, kidney, heart, spleen, ovaries and testes, and intestines, both in the treated male and female rats. Microscopic pictures $($ zoom $\times 100)$ of liver and kidney tissue of the treated male and female rats are shown in Figs. 1 and 2. Oral exposure to a single dosage of CrGly $(2,000 \mathrm{mg} / \mathrm{kg}$ body mass) did not cause any observable pathological changes in liver and kidney tissue.

Table 1 shows the overall somatic indices, such as body and internal organ masses, in the treated and control rats. As can be seen, none of the studied parameters obtained for the treated with CrGly male and female rats were significantly different from those of the control group.
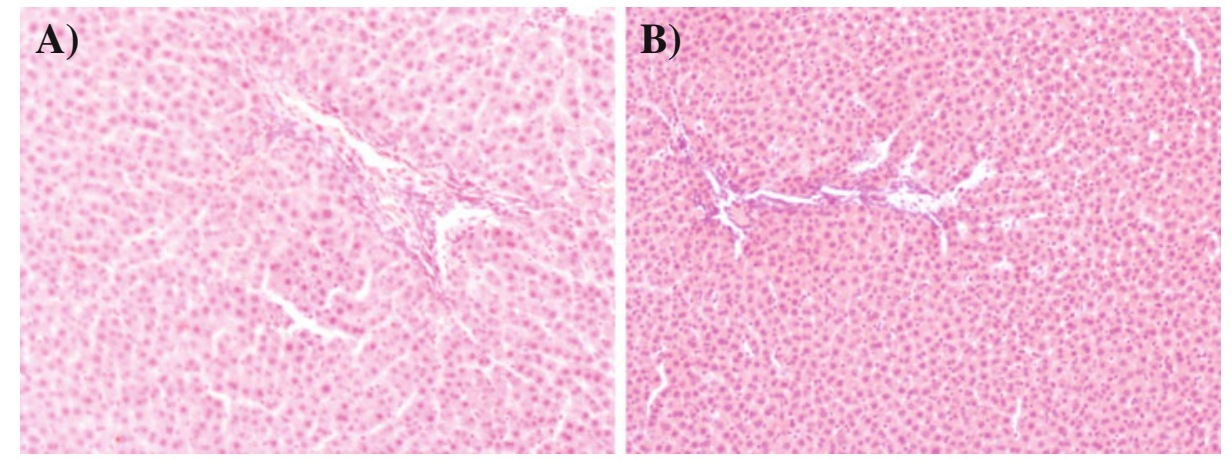

Fig. 1 Histopathological images of liver $($ zoom $\times 100)$ : a control group and $\mathbf{b}$ tested group exposure to CrGly at dose $2,000 \mathrm{mg} \cdot \mathrm{kg}^{-1}$ body mass 

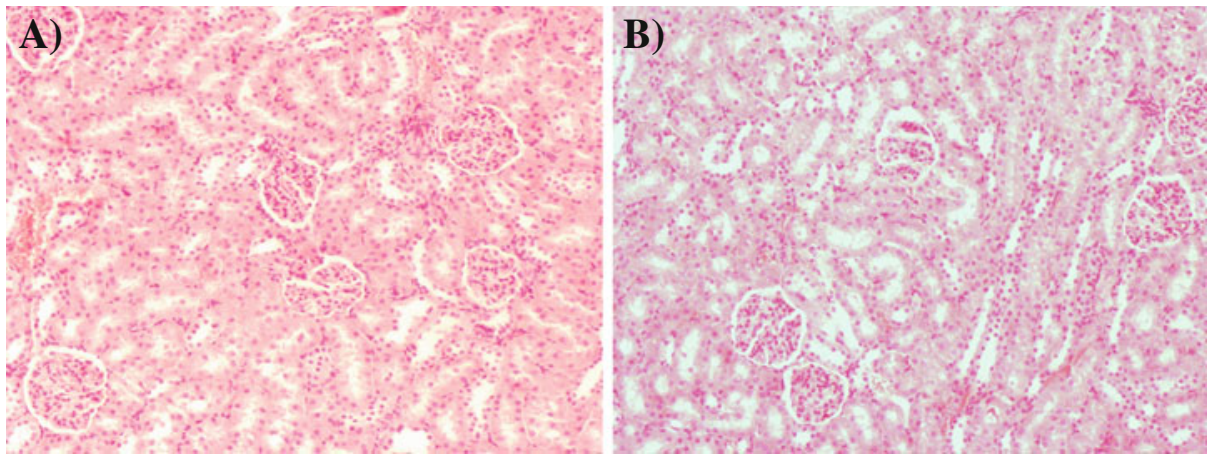

Fig. 2 Histopathological images of kidney (zoom $\times 100$ ): a control group and $\mathbf{b}$ tested group exposure to CrGly at dose $2,000 \mathrm{mg} \cdot \mathrm{kg}^{-1}$ body mass

Table 2 presents serum biochemical indices, including glucose, total cholesterol, HDL cholesterol, LDL cholesterol, triacylglycerols, urea, creatinine, total protein concentrations, serum $\mathrm{Na}, \mathrm{K}$, and Fe concentrations, as well as the activities of the enzymes (ALT, AST, and AP), in the treated and control male and female rats. None of the above parameters were changed in male and female rats treated with CrGly, in comparison with the control groups.

Table 1 Overall nutritional parameters of rats following exposure to 2,000 mg CrGly per kilogram body mass $($ mean $\pm \mathrm{SD})$

\begin{tabular}{|c|c|c|c|c|c|c|}
\hline \multirow[t]{2}{*}{ Parameter } & \multicolumn{2}{|l|}{ Male } & \multirow{2}{*}{$\begin{array}{l}\text { Student } \\
t \text { test }\end{array}$} & \multicolumn{2}{|l|}{ Female } & \multirow{2}{*}{$\begin{array}{l}\text { Student } \\
t \text { test }\end{array}$} \\
\hline & Control & $\begin{array}{l}\text { Tested CrGly } \\
2,000 \mathrm{mg} / \mathrm{kg} \\
\text { b.m. }\end{array}$ & & Control & $\begin{array}{l}\text { Tested CrGly } \\
2,000 \mathrm{mg} / \mathrm{kg} \\
\text { b.m. }\end{array}$ & \\
\hline Initial body mass ( $\mathrm{g}$ ) & $306.2 \pm 8.2$ & $306.2 \pm 4.3$ & NS & $174.2 \pm 12.3$ & $174.2 \pm 5.9$ & NS \\
\hline Food intake $(\mathrm{g})$ & $341 \pm 21$ & $309 \pm 37$ & NS & $280 \pm 43$ & $291 \pm 16$ & NS \\
\hline Body mass gain (g) & $24.250 \pm 8.057$ & $17.500 \pm 10.786$ & NS & $10.250 \pm 2.500$ & $8.250 \pm 2.872$ & NS \\
\hline $\begin{array}{l}\text { Feeding efficiency } \\
\text { ratio }(\mathrm{g} / 100 \mathrm{~g} \text { diet })\end{array}$ & $7.031 \pm 2.040$ & $5.405 \pm 2.942$ & NS & $3.649 \pm 0.604$ & $2.822 \pm 0.899$ & NS \\
\hline Final body mass (g) & $330 \pm 15$ & $324 \pm 8$ & NS & $184 \pm 12$ & $182 \pm 8$ & NS \\
\hline Liver mass (g) & $9.527 \pm 0.158$ & $9.327 \pm 0.328$ & NS & $4.962 \pm 0.217$ & $5.064 \pm 0.365$ & NS \\
\hline $\begin{array}{l}\text { Relative liver mass } \\
\text { (\% b.m.) }\end{array}$ & $2.886 \pm 0.096$ & $2.881 \pm 0.048$ & NS & $2.694 \pm 0.124$ & $2.772 \pm 0.099$ & NS \\
\hline Kidneys mass (g) & $2.247 \pm 0.097$ & $2.224 \pm 0.107$ & NS & $1.368 \pm 0.108$ & $1.305 \pm 0.032$ & NS \\
\hline $\begin{array}{l}\text { Relative kidneys } \\
\text { mass (\% b.m.) }\end{array}$ & $0.681 \pm 0.042$ & $0.687 \pm 0.024$ & NS & $0.741 \pm 0.033$ & $0.716 \pm 0.032$ & NS \\
\hline Spleen mass (g) & $0.706 \pm 0.048$ & $0.676 \pm 0.062$ & NS & $0.420 \pm 0.056$ & $0.421 \pm 0.036$ & NS \\
\hline $\begin{array}{l}\text { Relative spleen mass } \\
\text { (\% b.m.) }\end{array}$ & $0.214 \pm 0.023$ & $0.209 \pm 0.019$ & NS & $0.227 \pm 0.016$ & $0.231 \pm 0.027$ & NS \\
\hline Heart mass (g) & $0.945 \pm 0.069$ & $0.940 \pm 0.036$ & NS & $0.587 \pm 0.068$ & $0.580 \pm 0.038$ & NS \\
\hline $\begin{array}{l}\text { Relative heart mass } \\
\text { (\% b.m.) }\end{array}$ & $0.286 \pm 0.012$ & $0.290 \pm 0.008$ & NS & $0.317 \pm 0.017$ & $0.318 \pm 0.008$ & NS \\
\hline
\end{tabular}

$N S$ differences statistically non-significant 
Table 2 Blood serum indices of rats following exposure to 2,000 mg CrGly per kilogram body mass $($ mean \pm SD)

\begin{tabular}{|c|c|c|c|c|c|c|}
\hline \multirow[t]{2}{*}{ Parameter } & \multicolumn{2}{|l|}{ Male } & \multirow{2}{*}{$\begin{array}{l}\text { Student } \\
t \text { test }\end{array}$} & \multicolumn{2}{|l|}{ Female } & \multirow{2}{*}{$\begin{array}{l}\text { Student } \\
t \text { test }\end{array}$} \\
\hline & $\begin{array}{l}\text { Control } \\
\text { group }\end{array}$ & $\begin{array}{l}\text { Tested CrGly } \\
\mathrm{mg} / \mathrm{kg} \text { b.m. }\end{array}$ & & $\begin{array}{l}\text { Control } \\
\text { group }\end{array}$ & $\begin{array}{l}\text { Tested CrGly } \\
2,000 \mathrm{mg} / \mathrm{kg} \\
\text { b.m. }\end{array}$ & \\
\hline Glucose concentration $\left(\mathrm{mg} \cdot \mathrm{dl}^{-1}\right)$ & $98.5 \pm 15.9$ & $84.8 \pm 2.4$ & NS & $91.2 \pm 9.7$ & $98.2 \pm 8.8$ & NS \\
\hline $\begin{array}{l}\text { Total cholesterol concentration } \\
\left(\mathrm{mg} \cdot \mathrm{dl}^{-1}\right)\end{array}$ & $94.5 \pm 6.4$ & $90.8 \pm 8.9$ & NS & $86.8 \pm 10.7$ & $92.2 \pm 7.4$ & NS \\
\hline $\begin{array}{l}\text { LDL cholesterol concentration } \\
\qquad\left(\mathrm{mg} \cdot \mathrm{dl}^{-1}\right)\end{array}$ & $24.5 \pm 6.4$ & $26.5 \pm 4.4$ & NS & $22.0 \pm 5.5$ & $25.2 \pm 8.8$ & NS \\
\hline $\begin{array}{l}\text { HDL cholesterol concentration } \\
\left(\mathrm{mg} \cdot \mathrm{dl}^{-1}\right)\end{array}$ & $65.2 \pm 10.0$ & $58.8 \pm 4.3$ & NS & $60.0 \pm 5.7$ & $60.5 \pm 6.6$ & NS \\
\hline TAG concentration $\left(\mathrm{mg} \cdot \mathrm{dl}^{-1}\right)$ & $25.5 \pm 2.6$ & $29.2 \pm 8.3$ & NS & $26.0 \pm 2.4$ & $34.0 \pm 6.5$ & NS \\
\hline $\operatorname{ALT}\left(\mathrm{U} \cdot \mathrm{dm}^{-3}\right)$ & $34.8 \pm 6.6$ & $31.8 \pm 3.2$ & NS & $29.0 \pm 4.2$ & $28.5 \pm 3.3$ & NS \\
\hline $\operatorname{AST}\left(\mathrm{U} \cdot \mathrm{dm}^{-3}\right)$ & $94.5 \pm 5.3$ & $89.2 \pm 13.7$ & NS & $102.2 \pm 21.6$ & $119.2 \pm 46.6$ & NS \\
\hline $\operatorname{ALP}\left(\mathrm{U} \cdot \mathrm{dm}^{-3}\right)$ & $146.0 \pm 16.2$ & $131.8 \pm 22.7$ & NS & $118.2 \pm 19.4$ & $107.3 \pm 4.3$ & NS \\
\hline $\begin{array}{l}\text { Total protein concentration } \\
\left(\mathrm{g} \cdot \mathrm{dl}^{-1}\right)\end{array}$ & $6.2 \pm 0.2$ & $5.8 \pm 0.2$ & NS & $6.4 \pm 0.2$ & $6.3 \pm 0.1$ & NS \\
\hline $\begin{array}{l}\text { Creatinine concentration } \\
\left(\mathrm{mg} \cdot \mathrm{dl}^{-1}\right)\end{array}$ & $0.55 \pm 0.06$ & $0.52 \pm 0.05$ & NS & $0.48 \pm 0.05$ & $0.50 \pm 0.00$ & NS \\
\hline Urea concentration $\left(\mathrm{mg} \cdot \mathrm{dl}^{-1}\right)$ & $38.5 \pm 8.7$ & $35.8 \pm 2.6$ & NS & $34.8 \pm 5.2$ & $34.8 \pm 3.5$ & NS \\
\hline $\mathrm{Na}\left(\mathrm{mmol} \cdot \mathrm{dm}^{-3}\right)$ & $139.2 \pm 2.1$ & $140.0 \pm 1.4$ & NS & $137.5 \pm 5.8$ & $138.5 \pm 0.6$ & NS \\
\hline $\mathrm{K}\left(\mathrm{mmol} \cdot \mathrm{dm}^{-3}\right)$ & $4.2 \pm 0.1$ & $4.1 \pm 0.1$ & NS & $3.9 \pm 0.1$ & $4.0 \pm 0.4$ & NS \\
\hline $\mathrm{Fe}\left(\mu \mathrm{mol} \cdot \mathrm{dm}^{-3}\right)$ & $19.8 \pm 1.5$ & $14.8 \pm 3.5$ & NS & $67.0 \pm 7.9$ & $55.6 \pm 8.0$ & NS \\
\hline
\end{tabular}

NS differences statistically non-significant

Tables 3 and 4 show blood morphological and hematological indices, including WBC, RCB, LYMPH, PTL, MPV, PDW, hemoglobin, hematocrit, MCV, MCH, MCHC, and RDW values in the treated and control male and female rats. Most of these indices were not markedly different in animals treated with CrGly, except lower WBC (by 35\%), LYMPH

Table 3 Blood morphological indices of rats following exposure to 2,000 mg CrGly per kilogram body mass (mean $\pm \mathrm{SD})$

\begin{tabular}{|c|c|c|c|c|c|c|}
\hline \multirow[t]{2}{*}{ Blood index } & \multicolumn{2}{|l|}{ Male } & \multirow{2}{*}{$\begin{array}{l}\text { Student } \\
t \text { test }\end{array}$} & \multicolumn{2}{|l|}{ Female } & \multirow{2}{*}{$\begin{array}{l}\text { Student } \\
t \text { test }\end{array}$} \\
\hline & Control & $\begin{array}{l}\text { Tested CrGly } \\
2,000 \mathrm{mg} / \mathrm{kg} \text { b.m. }\end{array}$ & & Control & $\begin{array}{l}\text { Tested CrGly } \\
2,000 \mathrm{mg} / \mathrm{kg} \text { b.m. }\end{array}$ & \\
\hline WBC $\left(10^{9} \cdot \mathrm{dm}^{-3}\right)$ & $3.82^{\mathrm{b}} \pm 0.56$ & $2.50^{\mathrm{a}} \pm 0.42$ & $p<0.05$ & $1.48 \pm 1.02$ & $1.40 \pm 0.38$ & NS \\
\hline $\operatorname{RBC}\left(10^{12} \cdot \mathrm{dm}^{-3}\right)$ & $7.65 \pm 0.38$ & $7.41 \pm 0.23$ & NS & $7.46 \pm 0.18$ & $7.74 \pm 0.47$ & NS \\
\hline LYMPH $\left(10^{9} \cdot \mathrm{dm}^{-3}\right)$ & $3.5^{\mathrm{b}} \pm 0.6$ & $2.2^{\mathrm{a}} \pm 0.4$ & $p<0.05$ & $1.9 \pm 1.3$ & $1.3 \pm 0.3$ & NS \\
\hline $\operatorname{PLT}\left(10^{9} \cdot \mathrm{dm}^{-3}\right)$ & $1,182 \pm 104$ & $1,072 \pm 49$ & NS & $994 \pm 264$ & $1103 \pm 51$ & NS \\
\hline MPV (fl) & $6.85 \pm 0.10$ & $6.98 \pm 0.05$ & NS & $6.92 \pm 0.28$ & $6.88 \pm 0.15$ & NS \\
\hline PDW (fl) & $8.08 \pm 0.15$ & $8.08 \pm 0.15$ & NS & $8.08 \pm 0.35$ & $8.18 \pm 0.26$ & NS \\
\hline
\end{tabular}

Different letters indicate a statistically significant difference at $p<0.05$

$N S$ differences statistically non-significant, $R B C$ red blood count 
Table 4 Blood hematological indices of rats following exposure to 2,000 mg CrGly per kilogram body mass $($ mean \pm SD)

\begin{tabular}{|c|c|c|c|c|c|c|}
\hline \multirow[t]{2}{*}{ Blood index } & \multicolumn{2}{|l|}{ Male } & \multirow{2}{*}{$\begin{array}{l}\text { Student } \\
t \text { test }\end{array}$} & \multicolumn{2}{|l|}{ Female } & \multirow{2}{*}{$\begin{array}{l}\text { Student } \\
t \text { test }\end{array}$} \\
\hline & Control & $\begin{array}{l}\text { Tested CrGly } \\
2,000 \mathrm{mg} / \mathrm{kg} \mathrm{b.m.}\end{array}$ & & Control & $\begin{array}{l}\text { Tested CrGly } \\
2,000 \mathrm{mg} / \mathrm{kg} \mathrm{b.m.}\end{array}$ & \\
\hline Hemoglobin $\left(\mathrm{mmol} \cdot \mathrm{dm}^{-3}\right)$ & $14.6 \pm 0.5$ & $13.8 \pm 0.6$ & NS & $14.4 \pm 0.2$ & $14.5 \pm 0.6$ & NS \\
\hline HCT $(\%)$ & $42.7 \pm 2.0$ & $41.2 \pm 2.0$ & NS & $42.3 \pm 1.0$ & $43.1 \pm 1.7$ & NS \\
\hline $\operatorname{MCV}(f l)$ & $55.9 \pm 2.6$ & $55.6 \pm 1.1$ & NS & $56.8 \pm 1.4$ & $55.8 \pm 1.2$ & NS \\
\hline $\mathrm{MCH}(\mathrm{pg})$ & $19.1 \pm 0.7$ & $18.6 \pm 0.5$ & NS & $19.4 \pm 0.5$ & $18.7 \pm 0.4$ & NS \\
\hline $\operatorname{MCHC}\left(\mathrm{g} \cdot \mathrm{dl}^{-1}\right)$ & $34.1^{\mathrm{b}} \pm 0.4$ & $33.4^{\mathrm{a}} \pm 0.4$ & $p<0.05$ & $34.0 \pm 0.3$ & $33.6 \pm 0.3$ & NS \\
\hline RDW (\%) & $12.9 \pm 0.9$ & $13.1 \pm 0.7$ & NS & $12.7 \pm 0.4$ & $12.8 \pm 0.8$ & NS \\
\hline
\end{tabular}

NS differences statistically non-significant

(by $38 \%$ ), and $\mathrm{MCHC}$ (by $2 \%$ ) values only in the case of male rats in comparison with the appropriate control rats. However, these changes were still contained within the physiological ranges established for healthy rats.

Chromium(VI) compounds generally are considered as more toxic than chromium (III) compounds. For example, the $\mathrm{LD}_{50}$ for $\mathrm{K}_{2} \mathrm{Cr}_{2} \mathrm{O}_{7}$ (oral exposure) established in male and female rats (Fisher-344) were, 26 and $17 \mathrm{mg} / \mathrm{kg}$ body mass, respectively, for $\mathrm{CaCrO}_{4}$ in male and female rats (Sprague-Dawley), 249 and $107 \mathrm{mg} / \mathrm{kg}$ body mass, respectively [43].

The acute toxicity of a $\mathrm{Cr}$ (III) compound depends on its nature and solubility in water. Inorganic salts are more toxic than the organic ones. For example, $\mathrm{LD}_{50}$ for chromium nitrate $\left(\mathrm{Cr}\left(\mathrm{NO}_{3}\right)_{3} \cdot 9 \mathrm{H}_{2} \mathrm{O}\right)$ in male and female rats is 200 and $183 \mathrm{mg} \mathrm{kg}^{-1}$ body mass, respectively, while for chromium(III) acetate $\left(\mathrm{Cr}\left(\mathrm{CH}_{3} \mathrm{COO}\right)_{3} \cdot \mathrm{H}_{2} \mathrm{O}\right), \mathrm{LD}_{50}$ was evaluated as low ( $\mathrm{LD}_{50}=2,365 \mathrm{mg} \mathrm{kg}^{-1}$ body mass) [43]. The lower toxicity of chromium(III) acetate compared with chromium(III) nitrate may be related to its solubility, as chromium(III) acetate is less soluble in water than is chromium(III) nitrate.

Niacin-bound $\mathrm{Cr}$ (III) complex was found to be non-toxic for Sprague-Dawley male and female rats [44, 45], polynuclear $\mathrm{Cr}$ (III) complexes with natural ligands, including glycine, cysteine, glutathione, glutaminic, nicotinic, and asparaginic acids, such as: $\left[\mathrm{Cr}_{3}(\mathrm{Glu})_{3} \mathrm{Cys}(\mathrm{OH})_{2}\left(\mathrm{H}_{2} \mathrm{O}\right)_{6}\right],\left[\mathrm{Cr}_{4} \mathrm{Nic}(\mathrm{GSH})_{2}(\mathrm{OH})_{6}\left(\mathrm{H}_{2} \mathrm{O}\right)_{6}\right], \quad\left[\mathrm{CrNicCys}\left(\mathrm{H}_{2} \mathrm{O}\right)_{2}\right]$, $\left[\mathrm{Cr}_{2}(\mathrm{Asp})_{2}(\mathrm{GSH})(\mathrm{OH})_{3} \mathrm{H}_{2} \mathrm{O}\right] \cdot 4 \mathrm{H}_{2} \mathrm{O}, \quad\left[\mathrm{Cr}_{2}(\mathrm{Nic})_{2}(\mathrm{OH})_{4}\right] \bullet 4 \mathrm{H}_{2} \mathrm{O}, \quad\left[\mathrm{Cr}(\mathrm{Nic})_{2}(\mathrm{OH})\right] \bullet 3 \mathrm{H}_{2} \mathrm{O}$, mer- $\left[\mathrm{Cr}(\mathrm{Gly})_{3} \mathrm{H}_{2} \mathrm{O}\right] \cdot \mathrm{H}_{2} \mathrm{O}$, and fac- $\left[\mathrm{Cr}(\mathrm{Gly})_{3} \mathrm{H}_{2} \mathrm{O}\right] \cdot \mathrm{H}_{2} \mathrm{O}$, were found to be "non-toxic" $\left(\mathrm{LD}_{50}>2,000 \mathrm{mg} / \mathrm{kg}\right.$ body mass) for mice [46-48].

In our previous work, it was demonstrated that $\mathrm{LD}_{50}$ of CrProp is greater than $2,000 \mathrm{mg} \mathrm{kg}^{-1}$ body mass, when administrated orally to rat; thus, this complex appears to belong to the fifth category in the GHS system or the fourth class ("unclassified") in the EU classification system [11].

The results of this study assessing the acute oral toxicity of CrGly using both male and female Wistar rats, due to lack of lethal effects and no significant changes in gross and microscopic pictures of internal organs, as well as no sign of pathological changes blood biochemical and morphological indices, suggest that the tested compound should be classified (similarly to CrProp) to the fifth category in the United Nations Globally Harmonized System [49] or the fourth class ("unclassified," practically non-toxic) in the European Union classification system [50], which means that CrGly has low toxicity potential and relatively high safety margins for rat. 
In conclusion, the acute toxicity of many $\mathrm{Cr}$ (III) compounds had been determined, and most of them should be considered acutely non-toxic, unless the ligands are known to be toxic or the compounds are complexes of imines or related ligands that greatly shift the redox potential of $\mathrm{Cr}(\mathrm{III})$, such as $\mathrm{Cr}(\mathrm{bpy}) 3$ or $\mathrm{Cr}($ phen $) 3$ that are known toxins and mutagens [51, 52].

Acknowledgments The research described in this paper was funded by the Ministry of Education and Science (Grant No. 2 P06T 03830) in the years 2006-2009.

Conflict of Interest The authors declare that there are no conflicts of interest.

Open Access This article is distributed under the terms of the Creative Commons Attribution Noncommercial License which permits any noncommercial use, distribution, and reproduction in any medium, provided the original author(s) and source are credited.

\section{References}

1. Vincent JB (2000) The biochemistry of chromium. J Nutr 130:715-718

2. Vincent JB (2000) Elucidating a biological role for chromium at a molecular level. Acc Chem Res 33 (7):503-510

3. Vincent JB (2001) The bioinorganic chemistry of chromium(III). Polyhedron 20:1-26

4. Anderson RA (2003) Chromium and insulin resistance. Nutr Res Rev 16(20):267-275

5. Vincent JB, Bennett R (2007) Potential and purported roles of chromium in insulin signaling: The search for the holy grail. In: Vincent JB (ed) The nutritional biochemistry of chromium(III). Elsevier, Amsterdam, pp 139-160

6. Vincent JB (2010) Chromium: celebration 50 years as an essential element? Dalton Trans 39:3787-3794

7. Rhodes NR, McAdory D, Sharifa Love S, Bona KR, Chen Y, Ansorge K, Hira J, Kern N, Kent J, Lara P, Rasco JF, Vincent JB (2010) Urinary chromium loss associated with diabetes is offset by increases in absorption. J Inorg Biochem 104:790-797

8. Wang ZQ, Qin J, Martin J, Zhang XH, Sereda O, Anderson RA, Pinsonat P, Cefalu WT (2007) Phenotype of subjects with type 2 diabetes mellitus may determine clinical response to chromium supplementation. Metabolism 56(12):1652-1655

9. Wang ZQ, Cefalu WT (2010) Current concepts about chromium supplementation in type 2 diabetes and insulin resistance. Curr Diab Rep 10(2):145-151

10. Evans GW, Pouchnik DJ (1993) Composition and biological activity of chromium-pyridine carboxylate complexes. J Inorg Biochem 49(3):177-187

11. Staniek H, Krejpcio Z, Iwanik K (2010) Evaluation of the acute oral toxicity class of trinuclear chromium(III) propionate complex in rat. Food Chem Toxicol 48:859-864

12. Stout MD, Nyska A, Collins BJ, Witt KL, Kissling GE, Malarkey DE, Hooth MJ (2009) Chronic toxicity and carcinogenicity studies of chromium picolinate monohydrate administered in feed to F344/N rats and B6C3F1 mice for 2 years. Food Chem Toxicol 47:729-733

13. Harton A, Terrell K, Huffman JC, MacDonald C, Beatty A, Li S, O’Connor CJ, Vincent JB (1997) Synthesis and characterization of novel oxo-bridged dinuclear and hydroxo-bridged trinuclear chromium (III) assemblies. Inorg Chem 36(21):4875-4882

14. Sun Y, Ramirez J, Woski SA, Vincent JB (2000) The binding of trivalent chromium to low-molecularweight chromium-binding substance (LMWCr) and the transfer of chromium from transferrin and chromium picolinate to LMWCr. J Biol Inorg Chem 5(1):129-136

15. Clodfelder BJ, Emamaullee J, Hepburn DDD, Chakov NE, Nettles HS, Vincent JB (2001) The trail of chromium(III) in vivo from the blood to the urine: the roles of transferrin and chromodulin. J Biol Inorg Chem 6(5-6):608-617

16. Clodfelder BJ, Chang C, Vincent JB (2004) Absorption of the biomimetic chromium cation triaqua- $\mu 3$ oxo- $\mu$-hexapropionatotrichromium(III) in rats. Biol Trace Elem Res 98(2):159-169

17. Clodfelder BJ, Vincent JB (2005) The time-dependent transport of chromium in adult rats from the bloodstream to the urine. J Biol Inorg Chem 10(4):383-393 
18. Clodfelder BJ, Gullick BM, Lukaski HC, Neggers Y, Vincent JB (2005) Oral administration of the biomimetic $\left[\mathrm{Cr}_{3} \mathrm{O}\left(\mathrm{O}_{2} \mathrm{CCH}_{2} \mathrm{CH}_{3}\right)_{6}\left(\mathrm{H}_{2} \mathrm{O}\right)_{3}\right]^{+}$increases insulin sensitivity and improves blood plasma variables in healthy and type 2 diabetic rats. J Biol Inorg Chem 10(2):119-130

19. Bailey MM, Boohaker JG, Sawyer RD, Behling JE, Rasco JF, Jernigan JJ, Hood RD, Vincent JB (2006) Exposure of pregnant mice to chromium picolinate results in skeletal defects in their offspring birth defects. Res Part B Dev Rep Toxicol 77(3):244-249

20. Bailey M, Sturdivant J, Jernigan PL, Townsens MB, Bushman J, Ankareddi I, Rasco JF, Hood RD, Vincent JB (2008) Comparison of the potential for developmental toxicity of prenatal exposure to two dietary chromium supplements, chromium picolinate and $\left[\mathrm{CrPropO}\left(\mathrm{O}_{2} \mathrm{CCH}_{2} \mathrm{CH}_{3}\right)_{6}\left(\mathrm{H}_{2} \mathrm{O}\right)_{3}\right]^{+}$, in mice birth defects. Res Part B Dev Rep Toxicol 83(1):27-31

21. Kuryl T, Krejpcio Z, Wójciak RW, Lipko M, Debski B, Staniek H (2006) Chromium(III) propionate and dietary fructans supplementation stimulate erythrocyte glucose uptake and beta-oxidation in lymphocytes of rats. Biol Trace Elem Res 114(1-3):237-248

22. Staniek H, Krejpcio Z (2007) Effect of dietary Cr(III) supplementation on iron indices in rat. Interaction of xenobiotics. Polish Society of Toxicology, The Poznan Branch, pp 40-42 (in Polish)

23. Staniek H, Krejpcio Z (2009) The effects of tricentric chromium(III) propionate complex supplementation on pregnancy outcome and maternal and foetal mineral status in rat. Food Chem Toxicol 47:2673-2678

24. Staniek H, Krejpcio Z, Szymusiak H, Zieliński R (2007) The effect of high-doses of chromium(III) and quercetin on selected blond biochemical indices in rat. J Hum Nutr Metab 34(3/4):1069-1073 (in Polish, abstract in English)

25. Staniek H, Magdalena Kostrzewska-Poczekaj M, Arndt M, Szyfter K, Krejpcio Z (2010) Genotoxicity assessment of chromium(III) propionate complex in the rat model using the comet assay. Food Chem Toxicol 48:89-92

26. Speetjens J, Parand A, Crowder M, Vincent J, Woski S (1999) Low-molecular-weight chromium-binding substance and biomimetic $\left[\mathrm{Cr}_{3} \mathrm{O}\left(\mathrm{O}_{2} \mathrm{CCH}_{2} \mathrm{CH}_{3}\right)_{6}\left(\mathrm{H}_{2} \mathrm{O}\right)_{3}\right]^{+}$do not cleave DNA under physiologicallyrelevant conditions. Polyhedron 18:2617-2624

27. Wieczorek D, Zieliński R, Krejpcio Z, Szymusiak H (2005) Identification and purity control of nutritional chromium(III) supplements. In: Zieliński R, Wieczorek D (eds) Current trends in commodity science. Proceedings of the 8th international commodity science conference. The Poznan University of Economics Publishing House Poznan, pp 1284-1291

28. Wieloch A, Wieczorek D, Staniek H, Szymusiak H, Krejpcio Z, Zieliński R (2007) Tricentric complexes of chromium(III) with glycine and serine ligands. Current Trends in Commodity Science II:1080-1086

29. Maćkowiak P, Krejpcio Z, Sassek M, Kaczmarek P, Hertig I, Chmielewska J, Wojciechowicz T, Szczepankiewicz D, Wieczorek D, Szymusiak H, Nowak KW (2010) Evaluation of insulin binding and signaling activity of newly synthesized chromium(III) complexes in vitro. Mol Med Rep 3:347-353

30. Organization for Economic Cooperation and Development (OECD) (2001) The OECD 423 Guideline for Testing of Chemicals Acute Oral Toxicity - acute toxic class method, Paris, France. (http://iccvam.niehs. nih.gov/SuppDocs/FedDocs/OECD/OECD_GL423.pdf)

31. Schlede E, Genschow E, Spielmann H, Stropp G, Kayser D (2005) Oral acute toxic class method: a successful alternative to the oral $\mathrm{LD}_{50}$ test. Regul Toxicol Pharmacol 42(1):15-23

32. CELL-DYN 1700 SYSTEM (1995) Operations manual. Abbott Laboratories, USA

33. Sacks DB, Bruns DE, Goldstein DE, Maclaren NK, McDonald JM, Parrott M (2002) Guidelines and recommendations for laboratory analysis in the diagnosis and management of diabetes mellitus. Clin Chem 48:436-472

34. Miki Y (1999) A homogenous assay for the selective measurement of LDL-cholesterol in serum. Enzymatic selective protection method. Clin Lab 45:398-401

35. Riesen WF (1998) Lipid metabolism. In: Thomas L (ed) Use and assessment of clinical laboratory results. TH-Books Verlagssesellschaft, Frankfurt Main, pp 167-169

36. Shephard MD, Whiting MJ (1990) Falsely low estimation of triglycerides in lipemic plasma by the enzymatic triglyceride method with modified Trinder's chromogen. Clin Chem 36:325-329

37. Schumann G, Klauke R (2003) New IFCC reference procedures for the determination of catalytic activity concentrations of five enzymes in serum: preliminary upper reference limits obtained in hospitalized subjects. Clin Chim Acta 327:69-79

38. Newmann DJ, Price CP (1999) Renal function and nitrogen metabolites. In: Burtis CA, Ashwood ER (eds) Tietz textbook of clinical chemistry. WB Saunders Company, Philadelphia, pp 1239-1242

39. Thomas L (1998) Total protein. In: Thomas L (ed) Clinical laboratory diagnostics. Use and assessment of clinical laboratory results. TH-Books Verlagsgesllschaft, Frankfurt Main, pp 644-647

40. NCCLS (1998) The National Committee for clinical laboratory standards, determination of serum iron, total iron-binding capacity and percent transferrin saturation; approved standard. NCCLS Document H17-A. Pennsylvania: NCCLS 18: 1-40 
41. Woldring MG (1953) Flame photometric determination of sodium and potassium in some biological fluids. Anal Chim Acta 8:150-167

42. Zawistowski S (1983) Technika histologiczna Histologia oraz podstawy histopatologii. PZWL Warszawa (in polish)

43. ATSDR (2008) Draft toxicological profile for chromium U.S. Department of Health and Human Services Public Health Service. Agency for toxic substances and disease registry (www.atsdr.cdc.gov/toxprofiles/ tp7.pdf)

44. Shara M, Kincaid AE, Limpach AL, Sandstrom R, Barrett L, Norton N, Bramble JD, Yasmin T, Tran J, Chatterjee A, Bagchi M, Bagchi D (2007) Long-term safety evaluation of a novel oxygen-coordinated niacin-bound chromium (III) complex. J Inorg Biochem 101(7):1059-1069

45. Shara M, Yasmin T, Kincaid AE, Limpach AL, Bartz J, Brenneman KA, Chatterjee A, Bagchi M, Stohs SJ, Bagchi D (2005) Safety and toxicological evaluation of a novel niacin-bound chromium (III) complex. J Inorg Biochem 99(11):2161-2183

46. Galuszka G, Cieslak-Golonka M, Szelag A, Starosta J, Wojciechowska A (1998) Synthetic models for the glucose tolerance factor: the spectroscopic characterization and toxicity studies of monomeric and dimeric $\mathrm{Cr}(\mathrm{III})$ species. Polyhedron 17:3785-3794

47. Maciejewska G, Cieslak-Golonka M (2002) Homo- and hetero-nuclear chromium(III) complexes with natural ligands Part 2. Oxo- and hydroxo-bridged chromium(III)/vanadium(V) species. Trans Metal Chem 27:587-592

48. Maciejewska G, Cieslak-Golonka M, Staszak Z (2003) Homo- and hetero-nuclear chromium(III) complexes with natural ligands. Part 3. Chromium(III)/vanadium(IV) species isolated from the redox systems. Trans Metal Chem 28:96-102

49. United Nations (2007) Globally harmonized system of classification and labelling of chemicals (GHS), ST/SGAC.10/30/Rev.2.Chapter 3.1. fromhttp://www.enece.org/trans/danger/publi/ghs/ ghs_rev02/English/01e_part1.pdf

50. European Union, Council Directive 92/32/EEC of 30 April 1992 amending for the seventh time Directive 67/548/EEC on the approximation of the laws, regulations and administrative provisions relating to the classification, packaging and labelling of dangerous substances Fromhttp://eur-lex.europa. eu/LexUriServ/LexUriServ.do?uri=CELEX:31992L0032:EN:HTM

51. Rajaram R, Nair BU, Ramasami T (1995) Chromium(III) induced abnormalities in human lymphocyte cell proliferation: evidence for apoptosis. Biochem Biophys Res Commun 2:434-440

52. Warren G, Schultz P, Bancroft D, Bennett K, Abbott EH, Rogers S (1981) Mutagenicity of a series of hexacoordinate chromium(III) compounds. Mutat Res Genet Toxicol 90:111-118 